\title{
ESTIMATING MOISTURE ABSORPTION KINETICS OF SWORD BEANS DURING SOAKING USING MIDILLI MODEL
}

\author{
AWOTONA, E.O. ${ }^{*}$, ALADE, A.Oํ., ADEBANJO, S.A. ${ }^{2}$, \\ DUDUYEMI $O^{2}$. AND AFOLABI, T.J. ${ }^{1}$ \\ ${ }^{1}$ Department of Chemical Engineering, Ladoke Akintola University of Technology, Ogbomoso, Nigeria \\ ${ }^{2}$ Department of Chemical Engineering, Lagos State University, Epe Campus \\ *Corresponding author, email:estolu11@gmail.com
}

Received: 13th February 2020

Accepted: $28^{\text {th }}$ June 2020

Published: $20^{\text {th }}$ September 2020

https://doi.org/10.47545/etrj.2020.5.2.067

\begin{abstract}
Midilli model was used to estimate the moisture ratio of four varieties of Sword beans. The experiment was carried out using distilled water at temperature of $53^{\circ} \mathrm{C}$ for 100 minutes. The standard model of water absorption was fitted into the experimental data. Coefficient of determination $\left[\mathrm{R}^{2}\right]$ and root mean square error were used to evaluate the model. The Midilli model was chosen based on maximum value of Coefficient of determination and minimum value of root mean square error. The result showed that Midilli model is the most appropriate for TCG-4 with $\mathrm{R}^{2}$ value of 0.9924 and RMSE value of 0.1758 to estimate moisture ratio changes versus time in soaking. The moisture ratio against soaking time was plotted in each case using Midilli equation. The plotted curves of each variety of bean indicated that moisture ratio decreases with increasing in time. The effective moisture diffusivity coefficient of four varieties of varieties of Sword beans increased.
\end{abstract}

Keywords: Effective diffusivity, Hydration, Midilli model, Standard Model, Sword beans.

\section{INTRODUCTION}

Sword bean (Canavaliagladiate) is a fast-growing tropical legume, which is widely available in Nigeria [1]. Seeds of Canavaliagladiata contain $7.5 \%$ soluble sugars and $37.2 \%$ starch, on a fresh weight basis. The bean contains $23 \%$ $34 \%$ of protein, which is equivalent to soybeans [2]. The leaves of Sword beans plant have been used in treatment of persistent skin rashes. This crop is most useful as a cover crop that fixes nitrogen, and as a drought tolerant green manure. The vines and seeds, good sources of protein and starch, are used to feed livestock. The young pods are used as green vegetable and boiled seeds are widely consumed by tribal and village people in Southern India [3, 4]. Hydration is a very complex phenomenon that involves different physical mechanisms such as water imbibition, internal diffusion, convection at the surface and within large open pores, and relaxation of the solid matrix [5]. Soaking is a slow process controlled by the diffusion of water in the grain. Warm water is used for soaking purpose to shorten the soaking time because increasing temperature increases hydration rate [6].

The objective of this study is to determine if Midilli model could estimate moisture absorption kinetics of sword beans

\section{MEHODOLOGY}

\subsection{Kinetics Study of Water Absorption of the Dried Seeds of Varieties of Sword beans}

The approach of Kahiriet al., (2010) [7] was used to determine kinetic study of water absorption of dried seeds of varieties of Sword beans. 5 grams of selected varieties of Sword beans was weighed and soaked in five times weight of distill water at $53{ }^{\circ} \mathrm{C}$ for 100 minutes. Samples were periodically removed from the beakers, dried with dried wipes to remove surface moisture and weighed. Water content absorbed by the sample was calculated by the different between weight of the moisture content of each sample with the time, was used to plot the kinetic curve 


\subsection{Determination of the Effective Moisture Diffusivity Coefficient during Water Absorption Process}

Previous studies have shown that moisture transfer during water absorption of food samples occurs mainly through the distribution process such as diffusion. The effective moisture diffusivity in the selected seed samples was selected based on the Fick's second law expressed in Equation 1.

$\frac{\delta M}{\delta t}=\nabla^{2}\left[D_{e f f} M\right]$

where, $M$ is moisture content at time $t$ [dry basis. \%]; $D_{\text {eff }}$ is effective moisture diffusivity coefficient $\left(\mathrm{m}^{2} / \mathrm{s}\right)$.

Equation 2 can be written for spherical coordinates as Equation 2:

$\frac{\delta M}{\delta t}=\left[D_{e f f}\left(\frac{\delta^{2} M}{\delta r^{2}}+\frac{2 \delta M}{r \delta r}\right)\right]$

While, $\Pi$ is 3.142 and $r$ is grains spherical radius and algebraic solution of Equation 3 can be written as Equation 3:

$M R=\frac{6}{\Pi^{2}} \sum_{n=1}^{\infty} \frac{1}{n^{2}} \exp \left[\frac{-D_{e f f} n^{2} \Pi^{2}}{r^{2}} t\right]$

Where $M R$ is the moisture ratio [MR], $r$ is the radius of equivalent sphere; $t$ is the time and Deff is the effective diffusivity. Equation 4 can be made linear [5]. By ignoring higher-order, terms that contribute no significant change in the results, the first term of Equation 4 can be written as Equation (4)

$$
M R=\frac{6}{\Pi^{2}} \exp \left[\frac{D_{e f f} \Pi^{2}}{r^{2}} t\right]
$$

Logarithm of both sides of Equation (5) is presented as:

$$
\operatorname{Ln}(M R)=\operatorname{Ln}\left(\frac{6}{\Pi^{2}}\right)-\frac{D_{e f f} \Pi^{2}}{r^{2}} t
$$

A straight line with a slope $S$ was obtained, by plotting the natural logarithm of the data collected during the soaking test versus time; which is equal to coefficient of $t$ in Equation 6. The effective diffusion coefficient of moisture can be presented using Equation 8 [8].

$$
\begin{aligned}
& \text { Slopes }=\frac{D_{e f f} \Pi^{2}}{r^{2}} \\
& D_{e f f}=\frac{S-r^{2}}{\Pi^{2}}
\end{aligned}
$$

The quality of the fitted water absorption models were evaluated and compared by using statistical measures such as root mean square (RMSE) and coefficient of determination $\mathrm{R}^{2}$.For the best fit, the $\mathrm{R}^{2}$ value should be high and $R M S E$ values should be low [8].

$R M S E=\sqrt{\sum_{\mathrm{i}}^{\mathrm{n}}=1 \frac{\frac{\left.\mathrm{MR}_{\text {model, } \mathrm{i}} \mathrm{MR}_{\text {exp }, \mathrm{i}}\right]}{\mathrm{N}}}{\mathrm{MR}_{\exp }}} \times 100 \%$

Where $M R_{\text {exp }, i}$ isthe moisture ratio derived from the experiment and $M R_{\text {model, } i}$ the moisture ratio derived from the model. $M R_{\text {exp }}$ ismean moisture ratio obtained from experiments. $N$ is the number of observations [8]-[10].

The correlation coefficient $\mathrm{R}^{2}$ is a primary criterion for selecting the best equation to describe the water absorption curve equation (11). The correlation coefficient $R^{2}$ was calculated as: 


$$
\mathrm{R}^{2}=\frac{1-\text { Residual sum of squares }}{\text { Corrected total squares }}
$$

\section{RESULTS AND DISCUSSIONS}

\subsection{Mathematical Modeling Water Absorption Capacity of sword bean Seeds}

Table 1, presents the results of nonlinear regression analysis of fitting the Midilli model to the experimental data. The values of $\mathrm{R}^{2}$ and RMSE corresponding to the midilli model which described the moisture changes during soaking are listed in Table 1 . The predictability of the model was chosen based on the maximum value of coefficient of variationR ${ }^{2}$ and RMSE, The result showed that Midilli model was able to predict hydration of the varieties of sword beans with acceptable $\mathrm{R}^{2}$ values. Midilli model of TCG -4 with $\mathrm{R}^{2}$ values of 0.9924 and RSME value of0.1758 was used to predict moisture ratio changes versus time in soaking.

Tables 1: Coefficient of Determination $\left[\mathbf{R}^{2}\right]$ and Root mean square errors of Midilli model for selected varieties of sword beans

\begin{tabular}{lllllllll}
\hline Models & TCG-1 & & TCG-2 & & TCG-3 & & TCG-4 \\
& $\mathrm{R}^{2}$ & RMSE & $\mathrm{R}^{2}$ & RMSE & $\mathrm{R}^{2}$ & RMSE & $\mathrm{R}^{2}$ & RMSE \\
Midilli & 0.9905 & 0.6662 & 0.9225 & 2.3039 & 0.9541 & 2.5793 & 0.9924 & 0.1758 \\
\hline
\end{tabular}

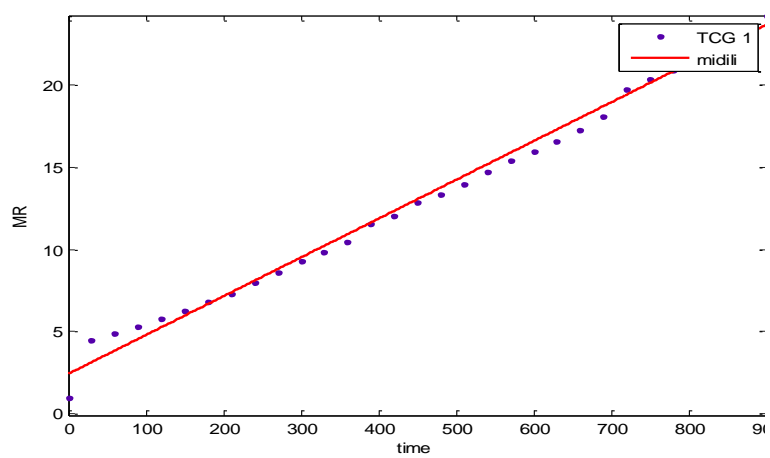

TG-1

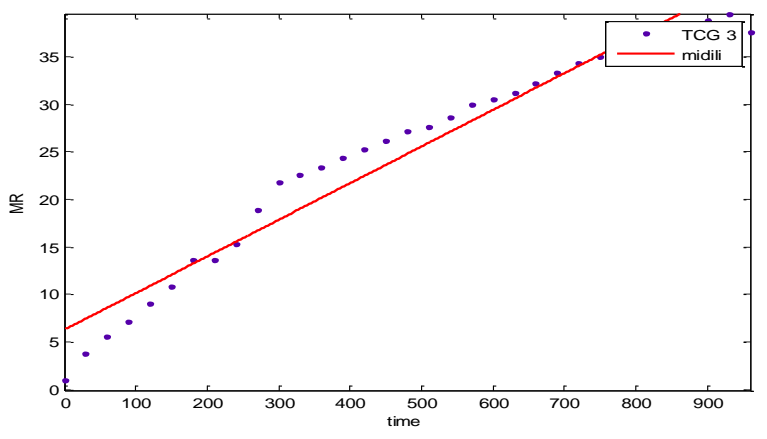

TG-3

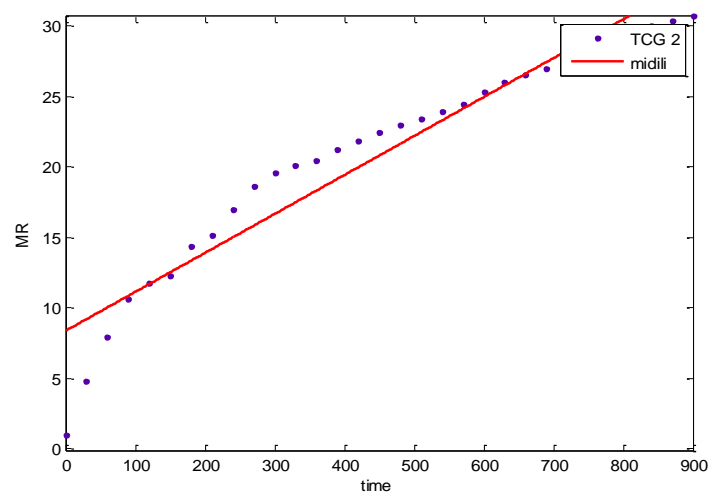

TG-2

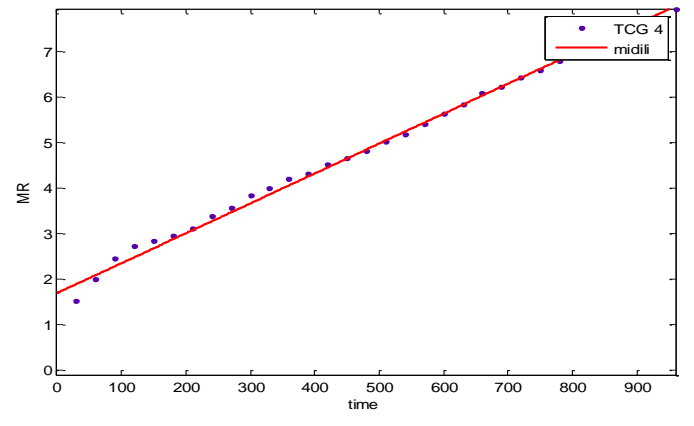

TG-4

Figure 1: Plots of midilli model for water absorption capacity of four varieties of sword bean seeds 


\section{2 Water Absorption curve of four varieties of sword bean seeds}

It was observed that the moisture gained is positively correlated $[R>0.92]$ with the square root of the soaking period at all the water soaking time. The experimental data of water soaking time Fig 2. In the first 30 minutes there was rapid water absorption. Table 1 , showed that Midilli model yielded acceptable $\mathrm{R}^{2}$. Comparison of $\mathrm{R}^{2}$ and RMSE values of midilli model indicated value of 0.9924 and RMSE of 0.1758 .

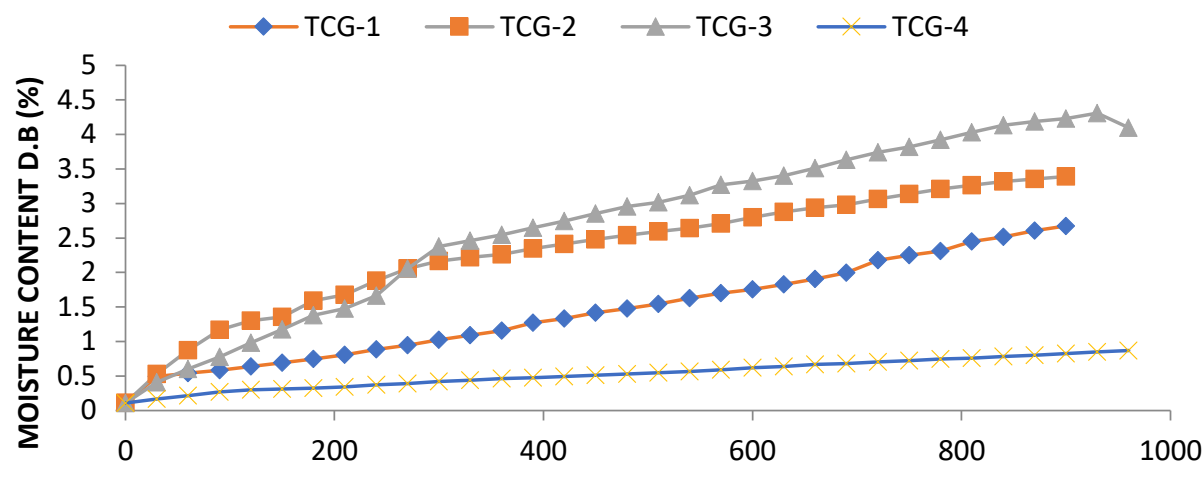

TIME (MIN)

Fig 2: Water absorption curve for four varieties ofswordbean at different time

\subsection{Effect of time on Moisture Diffusivity of Four Varieties of sword bean seeds}

The moisture diffusivity of sword beans varied from $3.07 \times 10-10$ to $9.40 \times 10-10 \mathrm{~m}^{2} / \mathrm{s}$. The volume and surface of varieties of sword beans increased faster which results in increasing effective moisture diffusivity coefficients. Similar report on chick pea seeds during soaking process has been published [12].

Table 2: Moisture diffusivity for four varieties of sword bean

\begin{tabular}{lll}
\hline Samples & $\mathrm{R}^{2}$ & $\mathrm{D}_{\text {eff }}\left[10^{-10}\right]\left[\mathrm{m}^{2} / \mathrm{s}\right]$ \\
\hline TCG-1 & 0.980 & 9.400 \\
TCG-2 & 0.933 & 4.805 \\
TCG-3 & 0.807 & 4.378 \\
TCG-4 & 0.784 & 3.067 \\
\hline
\end{tabular}

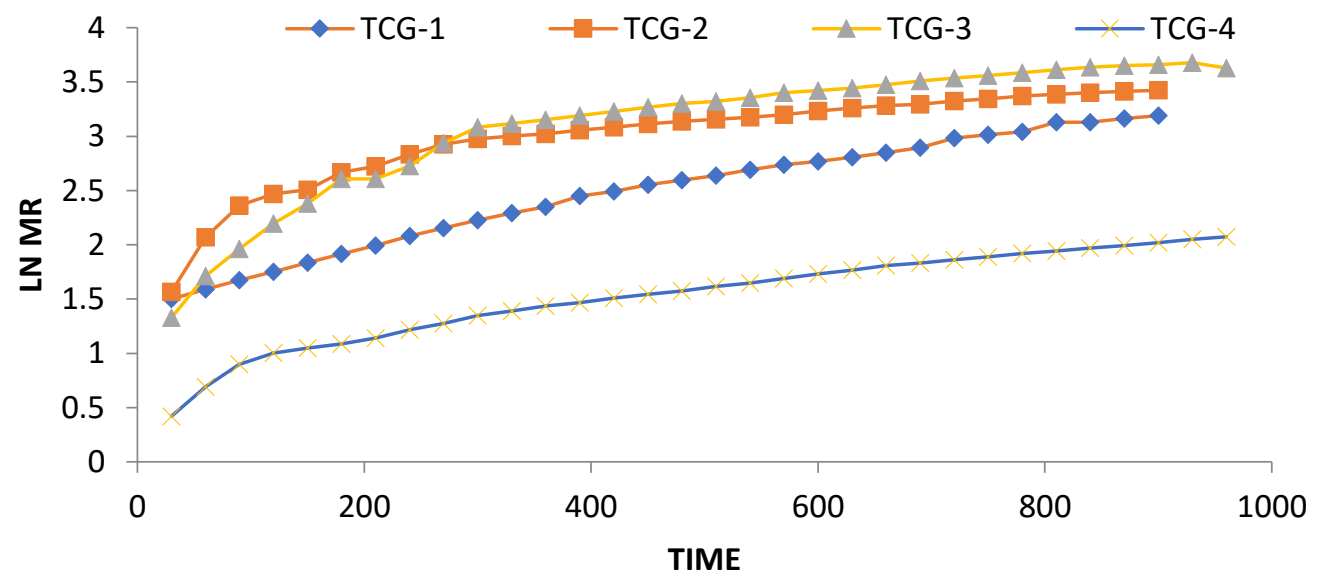

Figure 2: Effect of soaking time on the effective diffusivity of varieties of Sword bean. 


\section{CONCLUSION}

This research work presents the influence of time and temperature on moisture absorption kinetics of four varieties of Sword beans. The experimental data were subjected to nonlinear regression using midilli model. The midilli model predicted better water absorption of the four varieties of sword beans used in this study. Midilli model of TCG -4 has highest R2 values of0.9924 and lowest RSME value of0.1758 respectively.

\section{REFERENCES}

[1]. S. Ekanayake, E.R. Jams,M.N. Baboo,"Literature review of an underutilized legume: CanavaliagladiataL”. Plant Foods for Human Nutritional.Vol55, 2004, 305- 321.

[2]. A.S. Abitogun,G.K. Oso,"Assessment of Processing Methods on the Chemical Composition of Sword Bean (Canavaliagladiate)"IOSR Journal of Applied Chemistry.Vol7, No. 5, 2014, 106-112.

[3]. A.H. Akinmutimi, "Evaluation of Sword bean (Canavaliagaladiata).As an alternate feed resource for broiler chickens". Ph.D. Thesis, College of Animal science and Animal Health. Michael Okpara University of Agriculture, Umudike.2004, 4- 17.

[4].S. Ekanayake, E.R. Jams, A.M. Abeysekera, B.M. Nair, "Some anti-nutritional factors of mature Sword beans (Canavalia gladiate) ’Vidyodaya Journal ofScience. Vol. 10, 2001, 81-90

[5]. F.A.R. Oliveira,L. Ilincanu, "Rehydration of dried plant tissues: basic conceptsand mathematical modeling, in: F.A.R. Oliveira, J.C. Oliveira (Eds.), ProcessingFoods, CRC Press, Boca Raton,1999, 201-227.

[6]. A.N.C. Resio, R.J.Aguerre, C. Suarez, "Analysis of simultaneous water absorption and water-starch reaction during soaking of amaranth grain".Journal of Food Engineering vol. 68, 2005, 265-270.

[7]. M. Kashiri, M. Kashaninejad, N. Aghajani,"Modeling water absorption of sorghum during soaking”. Latin Am. App. Res., vol, 40, 2010, 383-388.

[8]. Z. Wang, J. Sun, F. Chen, X. Liao, X. Hu, "Mathematicalmodelling on thin layer microwave drying of apple pomacewithand without hot air pre-drying”. J. Food Eng. Vol. 80, 2007, 536-544.

[9]. V. Demir, T. Gunhan, A.K. Yagcioglu, A. Degirmencioglu, "Mathematical modeling and the determination of some quality parameters of air dried bay leaves". BiosystemsEngineering, vol. 88, 2004, 429-437.

[10]. I. Doymaz,“Drying Behavior of Green Beans”.Journal of Food Engineering.Vol. 69, No. 2, $2005,161-165$.

[11]. A. Midilli, H. Kucuk, Z. Yapar, “A new model for single-layer drying”.Drying Technol., vol. 20, No. 7, 2002, 1503-1513.

[12]. I. Doymaz, M. Pala, "The Thin-Layer Drying Characteristics of Corn”.Journal of Food Engineering.Vol. 60, No. 2, 2003, 125-130. 